Pak. j. sci. ind. res. Ser. A: phys. sci. 2018 61A(1) 35-42

\title{
Enhanced Storage Capacity and Quality of Haleji and Hadero Lakes Connecting with Indus River for their Sustainable Revival
}

\author{
Zia uddin Abro **, Abdul Latif Qureshi ${ }^{a}$, Shafi Muhammad Kori ${ }^{\mathrm{b}}$ and Ali Asghar Mahessar \\ ${ }^{a}$ US-Pakistan Centers for Advanced Studies-Water, Mehran University of Engineering \&Technology, \\ Sindh, Pakistan \\ ${ }^{b}$ Department of Civil Engineering, Mehran University of Engineering \&Technology, Sindh, Pakistan \\ 'Sindh Barrages Rehabilitation Project, Sindh Irrigation Department, Karachi, Pakistan \\ (received September 7, 2017; revised December 29, 2017; accepted December 29, 2017)
}

\begin{abstract}
Over $50 \%$ of wetlands in the world have been lost in the past century, and the remaining wetlands have been degraded to different degrees because of the adverse influences of human activities and climate change impacts. Though protected under Ramser convention, the situation of Haleji wetland complex and Hadero wildlife sanctuary is not very promising. The current paper is focusing to revitalize the abandoned and devastated Ramsar site "Haleji Wetland Complex" and a forgotten wetland "Hadero Wildlife Sanctuary", situated in Thatta district, Sindh province of Pakistan. Both these wetlands are of great importance for natural habitat and reducing risk of coastal disasters and floods. The study mainly employed Arc-Hydro tools using remotely sensed data of ASTER GDEM 2 to determine the topography of both wetlands and their possibilities to connect with freshwater sources, and leeway to increase their respective water holding capacity. The study reveals that all the three wetlands can be re-connected with Indus River to turn them into fresh water bodies for sustaining natural habitat and increasing water harvesting capacities to cater human drinking water needs
\end{abstract}

Keywords: wetlands, groundwater quality, natural habitat, remote sensing

\section{Introduction}

Current global population is around 7.2 billion and is still growing with increasing pace, while the earth's total resources are shrinking and scattered unevenly. The way we are living, we are already consuming two to three times more of the earth's natural resources than what is sustainable. The increasing population, depleting resources and changing climatic conditions have inverse impacts on the natural eco-system of earth.

Water is one among three main resources on Earth which are depleting at higher rate. Only $2.5 \%$ of the world's total water is fresh, out of which $70 \%$ is frozen in the shape of glaciers and icebergs. The remaining is in the form of ground water, rivers and wetlands. Wetlands are considered as the kidneys which serve to filter runoff water which sustain life in many ways. Wetlands too need to be refreshed by periodic supply of river water, precipitation and healthy biological activities. They settle pollutants such as phosphorus and heavy metals in their soils, transform dissolved nitrogen into nitrogen gas, and break down suspended solids to neutralize harmful bacteria (Seminara et al., 2011).

*Author for correspondence; E-mail: Ziadinabro@yahoo.com
The destruction of wetlands is a concern because they are some of the most productive habitats on the planet. They often support high concentrations of animalsincluding mammals, birds, fish and invertebrates. Wetlands serve as nurseries for many of these species (WWF, 2017). Apart from the serving as nurseries for fish and birds species, wetlands also serve as flood protection facilities for communities living around the wetlands (Marsooli et al., 2016). Thus they provide a range of ecosystem services that benefit humanity, including water filtration, disaster risk reduction, flood control and recreation (Greb et al., 2006).

Despite the general arid climate of country, Pakistan has more than 225 significant wetland sites, estimating on area about $7,800 \mathrm{~km}^{2}$ which covers $9.7 \%$ of the total surface area of the country (Kazmi et al., 2006) which was once home of biodiversity and heaven for migratory birds. Later due to shortage of river flows, overexploitation of groundwater, and construction of dams, the wetlands became polluted and reduced in size. The other studies on the devastation of wetlands included extensive surveys made by Fraser and Keddy (2005); Koning and Walmsley (1972), Savage and Isakov (1970). Savage (1967); also indicated the depleting situation of wetlands. 
In year 1971 Ramsar convention was held in Ramsar, Iran and declared 19 sites in Pakistan as protected and recognized as Ramser sites along with hundreds other sites all over the world. The other endangered locations were listed by Government of Pakistan and declared them as protected sites, wildlife sanctuary and gem sanctuary. Indus delta, Haleji wetland, and Keenjhar wetland are among the Ramser protected sites while Hadero Lake is protected by Government of Pakistan Laws of Wildlife Sanctuary.

The current situation of Indus delta and both Haleji and Hadero wetlands is not very promising. The continuous environmental degradation, and pollution, scarcity of rainfall and shortage of inflow of river water, increasing human induced activities and atrocities with natural atmosphere like deposition of industrial drainage effluent (Qureshi et al.,2015) tend to deteriorate the wetland eco-system with a steady and alarming pace (Zhao et al., 2016). The increasing population of cosmopolitan city Karachi demands new strategies to cater the needs of water for drinking, industrial, agricultural and more importantly for environment sustainability. The current paper focuses to interconnect (Golden et al., 2014) the adjacent wetlands with each other and with source of fresh water.

Research study area. The study area falls under the administrative boundaries of district Thatta of Sindh, Pakistan, along the right bank of River Indus. The area masked for study purpose comprising of Haleji wetland complex, Hadero and Keenjhar Lakes, is about 1,123 $\mathrm{km}^{2}$.

The western side is rocky mountaineous area; southwest is Arabian Sea approximate $50 \mathrm{kms}$ away, while on eastern side River Indus is flowing with fertile flat plateau towards Indus Delta (Fig. 1).

Hadero Lake. Lake Hadero is situated at $6752^{\prime} \mathrm{E}$ and $24^{\circ} 49^{\prime} \mathrm{N}$. It lies about $85 \mathrm{~km}$ to the east of Karachi. Hadero is set on the edge of stony desert. It is a natural lake in a shallow depression. Hadero Lake is situated within the radius of $5 \mathrm{~km}$ of Haleji lake wildlife sanctuary and about $16 \mathrm{~km}$ to the south-west of Keenjhar Lake wildlife sanctuary. Hadero Lake was declared wildlife sanctuary with objects to conserve and protect the natural environment in and around the Lake for different migratory and resident birds. It was initially protected for shooting purpose in year 1971 keeping in view its adjacent larger wetlands only appear/filled in heavy monsoon/rainfall season.

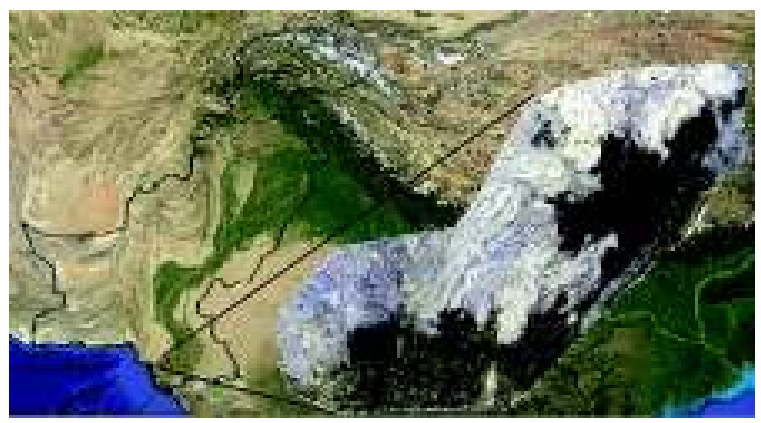

Fig. 1. Satellite image highlighting the study area

Haleji Lake. Haleji is an earth-filled artificial lake, spread over an area of $6.58 \mathrm{~km}^{2}(1,704 \mathrm{ha})$ with water level of about $1-1.5 \mathrm{~m}$ and maximum depth of about 5 $6 \mathrm{~m}$. It is located at $067^{\circ} 46^{\prime} \mathrm{E}$ and $24^{\circ} 47^{\prime} \mathrm{N}$ with $60 \mathrm{~m}$ elevation from mean sea level. The area is silty, muddy and sandy. The lake is situated at a distance of $21 \mathrm{~km}$ from Thatta and $88 \mathrm{~km}$ from Karachi. It is a perennial freshwater lake with associated marshes and adjacent brackish seepage lagoons, set in stony desert of limestone and sandstone bedrocks. This lake was a saline lagoon and in late 1930s it was converted into reservoir to feed $28 \mathrm{MGD}$ to Karachi as the first water supply source for thousands of American and British troops stationed in Karachi during World War II. Haleji Lake is also considered Asia's largest bird sanctuary. Since it attracts thousands of migratory birds between November to February. It can be termed a paradise for bird lovers. Halej Lake used to supply water to Karachi before year 2006. Water used to be supplied to Haleji Lake from Kalri Baghar feeder and then it was supplied to Karachi. After the construction of a direct supply line to Karachi from Keenjhar, the water of the lake has become stagnant which has resulted in the deterioration of water quality. Due to passage of time, local inhabitants dug out illegal water courses (small channels) from the Jamwah branch (which was feeding river water to Haleji Lake) and cut off the supply of fresh water to Haleji Lake.

Figure. 2 shows the detailed locations of Keenjhar, Haleji and Hadero Lakes along with adjacent small lakes and their respective connecting canals.

\section{Materials and Methods}

Field survey. Field survey has been conducted to check the actual ground situation, ground truthing and collection of water samples for physicochemical analysis. 


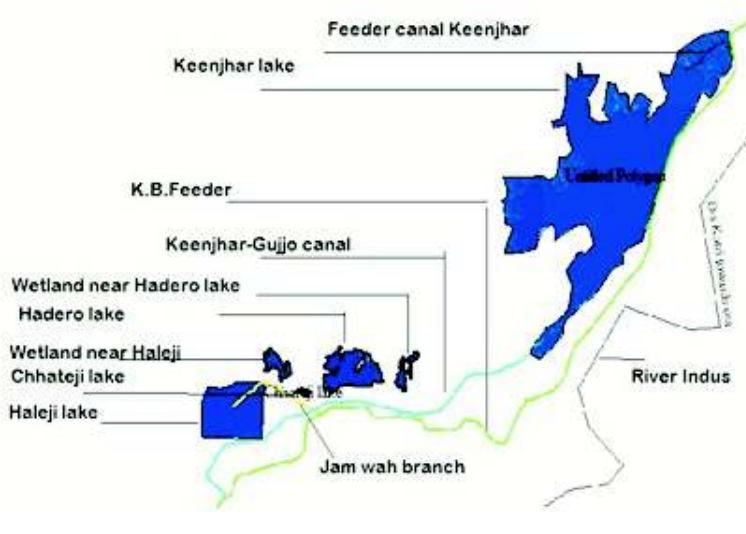

Fig. 2. Wetlands in study area with feeder canals

The field survey also included the interviews of key informants, and two focus group discussions (FGDs) on close ended questionnaires designed for the purpose of identifying the KAP (knowledge, attitude and practices), and solutions based on the local knowledge and folk wisdom. Transect walks have been conducted with FGDs participants along wetlands to understand ground situations and confirming the remotely sensed data acquired through satellites. The main elevation points which were remotely sensed through Google Earth pro were physically recorded through GARMIN 64 s handheld GPS device.

Physiochemical analysis. Water samples for water quality analysis have been collected from different locations of both wetlands and water sources. However, previous research studies conducted by various researchers have been referred to determine the physicochemical situation of water quality. The main physicochemical parameters which have been studied were $\mathrm{pH}$, dissolved oxygen (DO), electric conductivity (EC), total dissolved solids (TDS), chloride (Cl), sulphates $\left(\mathrm{SO}_{4}\right)$, sodium $(\mathrm{Na})$, magnesium $(\mathrm{Mg})$, potassium $(\mathrm{K})$ and hardness.

Remotely sensed revival plan. Google Earth and Global mapper have been used on ASTER GDEM V002 data to quantify the amount of water to be stored and possibilities to connect all reservoirs with river through Keenjhar Lake or directly with river Indus through Kalri Baghar (KB) Feeder. The elevation profiles are constructed using Google Earth pro, whereas volumes of reservoirs have been calculated using global-mapper cut and fill volume calculator method.

\section{Results and Discussion}

Field survey. Key informants interviews (KII) have been conducted with the curator of Haleji wetland and an official of Sindh Irrigation and Drainage Authority. They disclose that the fresh water supply to Haleji is not regular and only the additional available water is diverted to lake during rainfall season. They also confirmed that a revival plan of Haleji is under consideration with government of Sindh to increase its capacity for providing drinking water to cosmopolitan Karachi. The officials were also discussed about possibilities of connecting all wetlands with fresh water source to increase the water harvesting and improving the quality of lakes. The officials were of the view that a thorough physical survey will be required to chalk out the possibilities of connecting surrounding wetlands with fresh water source.

Two FGDs were also conducted, one in the village Usman Hallo situated in the vicinity of Haleji Lake and other in village Jumo Mallah on the bank of Hadero Lake. The participants of FGDs were of the opinion to refresh the wetlands through river water, and control hunting of migratory birds in the lakes. The transect walk along Haleji Lake identifies one water course which was illegally drawn from the Jam Wah branch (which feeds water to Haleji Lake) before it reaches the inlet of Haleji Lake. The FGD participants told that some influentials have cultivating government land in wetland areas under the supervision of concerned officials.

The KAP analysis revealed that however people were of the opinion to revive the wetlands but they were not willing to contribute by not polluting the lakes or stop taking water illegally from the feeding canals. Despite the fact that the water quality of Hadero was much beyond the permissible limits for drinking purpose, the local people claims that they use water for drinking as well as household purposes.

Physicochemical analysis. Khan et al. (2012) conducted a research on environmental pollution effects on natural habitat of Heleji and Keenjhar Lakes. The data was collected from year 2006 to year 2009. Four-years study discovered that pesticide contamination of organophosphate (OP) and organochlorine (OC) were above the maximum acceptable concentration (MAC) in Haleji Lake, while it was below MAC in Keenjhar Lake.

Further investigations revealed that the KB feeder canal was the major source of pollution. KB feeder canal off- 
takes from GM barrage, and feed water to Keenjhar Lake. While passing through Kotri Industrial area, the hazardous effluent from different industrial units is dumped into KB feeder canal without any environmental treatment. That hazardous chemical waste is dumped round the year. The researchers' analysis of Haleji Lake during the study period identified the issue of depleting dissolved oxygen in lake water which imposes threat to natural habitat.

Another study was conducted by Mahessar et al. (2015) (Table 1) on environmental impacts and threats to Haleji Lake, which reveals that the dissolved oxygen level of the lake water was around $3 \mathrm{mg} / \mathrm{L}$, which was less than the permissible limits defined by National Environmental Quality Standards (NEQS). The other parameters were found within permissible range defined by NEQS except at few locations with higher concentrations.

The above study was not limited to physicochemical analysis but a physical survey was also conducted to record the facts behind deterioration of the lake. On the basis of physicochemical analysis, it revealed that the depleting oxygen level in lake water poses a great threat to habitat. Similar findings revealed from physical survey recorded that migratory birds and natural habitat of lake is reducing day by day (Khan et al., 2014; Aziz et al., 2013; Fisher et al., 2008). The research concludes to divert fresh river water to increase the oxygen level of the lake.

The current study however, is not directly involved with detailed physicochemical analysis of lake waters but selected water quality parameters were analysed to determine the quality of water of both lakes to be interconnected for extending and enhancing water harvesting

Table 1. Physicochemical analysis (Mehassar et al., 2015)

\begin{tabular}{lll}
\hline \hline Parameter & $\begin{array}{l}\text { Available } \\
\text { range }\end{array}$ & $\begin{array}{l}\text { Permissible } \\
\text { limits(NEQS) }\end{array}$ \\
\hline $\mathrm{pH}$ & $6-8$ & $6.2-8.5$ \\
$\mathrm{DO}$ & $3-4$ & $>8$ \\
$\mathrm{EC}(\mu \mathrm{S} / \mathrm{cm})$ & $400-1180$ & 680 \\
$\mathrm{TDS}(\mathrm{mg} / \mathrm{L})$ & $250-800$ & 1000 \\
$\mathrm{CC}(\mathrm{mg} / \mathrm{L})$ & $50-175$ & 250 \\
Sulphate $(\mathrm{mg} / \mathrm{L})$ & $45-75$ & 250 \\
Sodium $(\mathrm{mg} / \mathrm{L})$ & $50-150$ & 200 \\
Magnesium(mg/L) & $20-40$ & 150 \\
Potassium $(\mathrm{mg} / \mathrm{L})$ & $8-18$ & 12 \\
Hardness & $190-180$ & 500 \\
\hline \hline
\end{tabular}

during heavy monsoon and flooding years. Figure 3 indicates the points from where water samples were collected for current study. The results of the water samples collected from Haleji wetland complex and Hadero Lake are given in Table 2. The chemical analysis of sample "S6" (Hadero Lake) shows a very higher concentration of minerals and dissolved salts. The rest of the samples from inlets and outlets of Haleji Lake, were found within the permissible limits of WHO for drinking purpose and in association with the findings of Mahessar et al. (2015) and Khan et al. (2012). Sample $\mathrm{S} 5$ was collected from the drain (RBOD) which is under construction on the right side of river Indus passing along with Hadero and Haleji Lakes.

Remotely sensed revival plan. The remotely sensed data ground truthed by field verification were used to analyse the possibilities of interconnecting wetlands on right side of river Indus and quantifying their water holding capacities using different remote sensing tools and applications. Google image of August 2016 was analysed for elevation difference of Keenjhar Lake and Haleji Lake. The elevation profile of Keenjhar-Gujjo

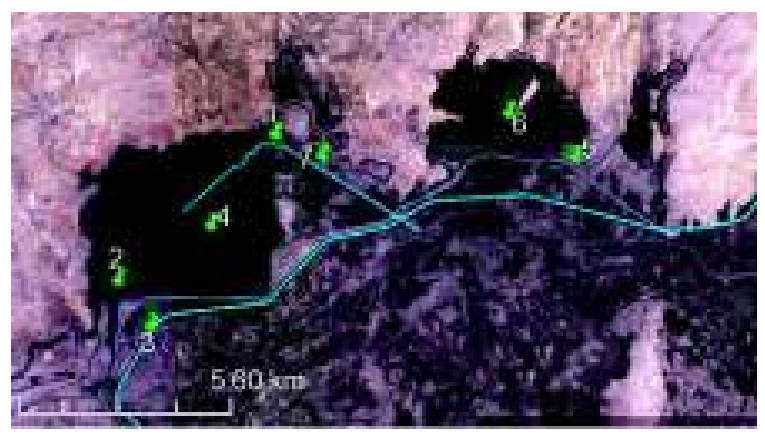

Fig. 3. Water sample collection points

Table 2. Water quality analysis for current study

\begin{tabular}{lllll}
\hline \hline $\begin{array}{l}\text { Water } \\
\text { quality } \\
\text { parameter }\end{array}$ & $\begin{array}{l}\text { Electrical } \\
\text { Conductivity } \\
(\mu-\mathrm{S} / \mathrm{cm})\end{array}$ & $\begin{array}{l}\text { Hardness } \\
\mathrm{CaCO}_{3} \\
(\mathrm{mg} / \mathrm{L})\end{array}$ & $\begin{array}{l}\mathrm{pH} \\
(30.50 \mathrm{C})\end{array}$ & $\begin{array}{l}\mathrm{TDS} \\
(\mathrm{mg} / \mathrm{L})\end{array}$ \\
\hline $\begin{array}{l}\text { Permissible } \\
\text { Limits results }\end{array}$ & NGVS & 500 & $6.5-8.5$ & 100 \\
S1 & 619 & $(\mathrm{WHO})$ & $(\mathrm{WHO})$ & $(\mathrm{WHO})$ \\
S2 & 1,073 & 220 & 7.3 & 396 \\
S3 & 1,161 & 270 & 7.3 & 686 \\
S4 & 1,273 & 320 & 7.2 & 743 \\
S5 & 1,785 & 510 & 7.3 & 814 \\
S6 & $1,9,280$ & 3,190 & 7.7 & 1,142 \\
S7 & 954 & 260 & 7.6 & 610 \\
\hline \hline
\end{tabular}


Canal off taking at Chilia passing nearby $(0.8 \mathrm{~km})$ from Hadero Lake and $1.2 \mathrm{kms}$ from Chhateji Lake (dried lake revealed by temporal detection of landsat imageries) shows a drop $14.6 \mathrm{~m}$ over $17.7 \mathrm{kms}$ (at siphon near Jam wah branch). Similar trend of elevation difference was recorded in $\mathrm{KB}$ Feeder from adjacent locations from Keenjhar -Gujjo channel. However de-silting of Keenjhar-Gujjo channel will be required from $5.6 \mathrm{kms}$ to $10.78 \mathrm{kms}$ from off-taking point to feed required quantity of water to proposed lakes. The designed inlet to feed Haleji Lake was Jam Wah branch off-taking from $\mathrm{KB}$ feeder at $67^{\circ} 50^{\prime} 22.14^{\prime \prime} \mathrm{E}$ and $24^{\circ} 48^{\prime} 6.41^{\prime \prime} \mathrm{N}$. Jam Wah branch is passing under Keenjhar -Gujjo canal at $67^{\circ} 50^{\prime} 3.35^{\prime \prime} \mathrm{E}$ and $24^{\circ} 48^{\prime} 16.56^{\prime \prime} \mathrm{N}$. The FGDs also resulted in the knowledge base of availability of three lakes adjacent to Hadero and Haleji Lakes. The name of Chhateji Lake was identified as separate Lake while other two lakes identified in the Fig. 2 revealed as the extension of Hadero and Haleji Lakes, respectively. These water bodies were also recognized through historical Google images during wet years, later they were verified through transect walk and FGDs. The outline polygons of wetted perimeters were developed in Google map and exported as layer to Global mapper v 18 for further analysis. The imported layers of wetlands in Global mapper were imposed on the ASTER GDEM V2 worldwide elevation data (1 Arc second resolution) to get three-dimensional measurements of the water bodies. Similarly possible sources connecting all wetlands were also marked through polylines and imported in Global mapper as KML files.

Figure 4 shows the drawn elevation profiles of water channel feeding Keenjhar Lake from KB Feeder (189 RD) shows a drop of $5 \mathrm{~m}$, over the length of $4.62 \mathrm{kms}$, but due to silt and vegetation the channel is silted $2 / 3 \mathrm{rd}$ of its total length, thus limiting the intake of water from KB feeder. Same elevation points were re-confirmed through GARMIN GPS handheld device and confirmed the elevation difference and obstacles in channel bed. The situation was discussed with the officials of irrigation department and they confirmed that de-siltation was not done from last few years.

Figure 5 shows the elevation profile of Jamwah canal feeding Haleji Lake from KB Feeder. A drop of $6 \mathrm{~m}$ was recorded over the total length of $7.9 \mathrm{kms}$ starting from Jamwah off-taking point from KB feeder to the location having maximum depth in Haleji Lake. Again some de-silting and excavation will increase the water intake to fill the reservoir at its maximum level. Apart from the original design there is also a possibility to connect Jamwah branch with Keenjhar-Gujjo canal at $67^{\circ} 50^{\prime} 3.18^{\prime \prime} \mathrm{E}$ and $24^{\circ} 48^{\prime} 16.58^{\prime \prime} \mathrm{N}$ as Keenjhar-Gujjo canal is siphoning over the Jamwah branch on mentioned location. The elevation differences were re-confirmed through GARMIN GPS handheld device during ground truthing process.

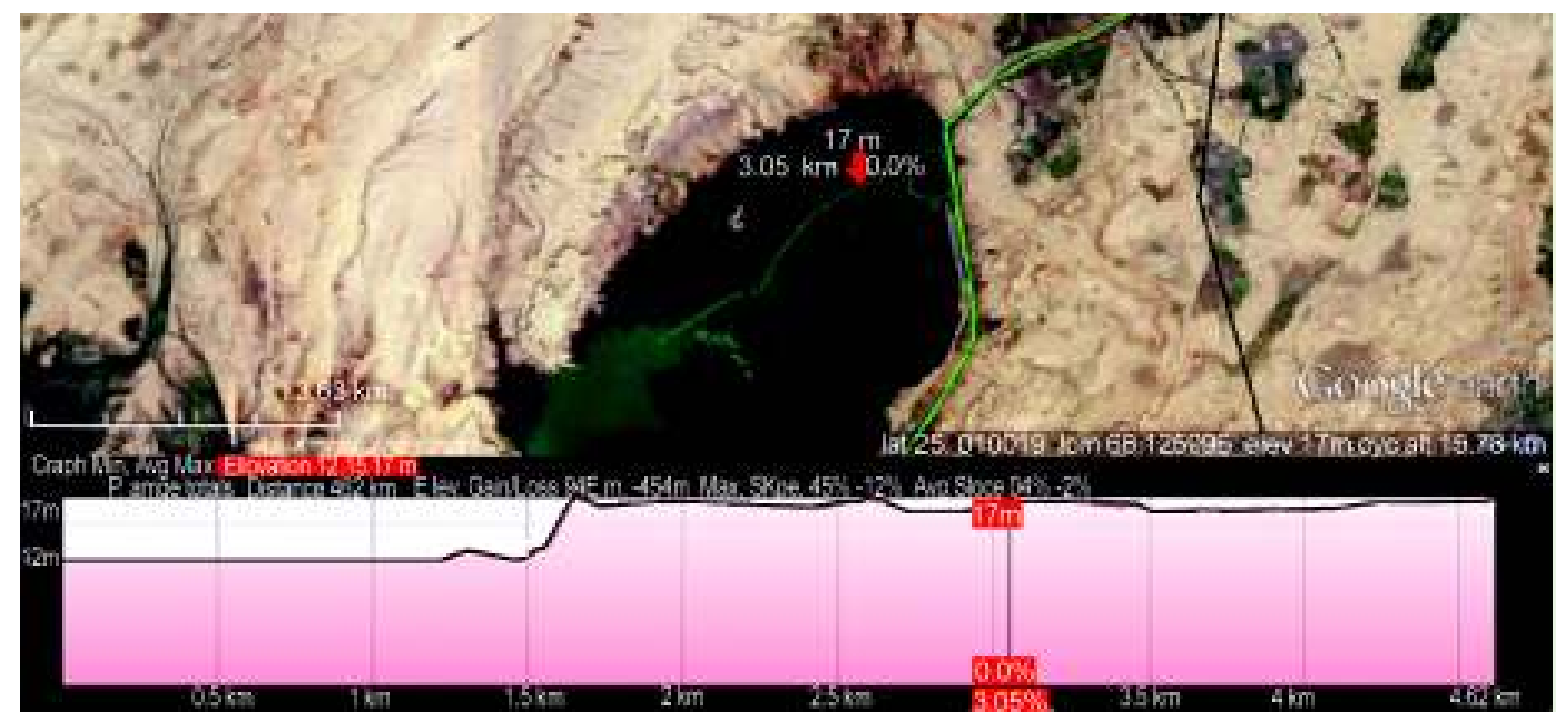

Fig. 4. Elevation profile canal feeding Keenjhar 


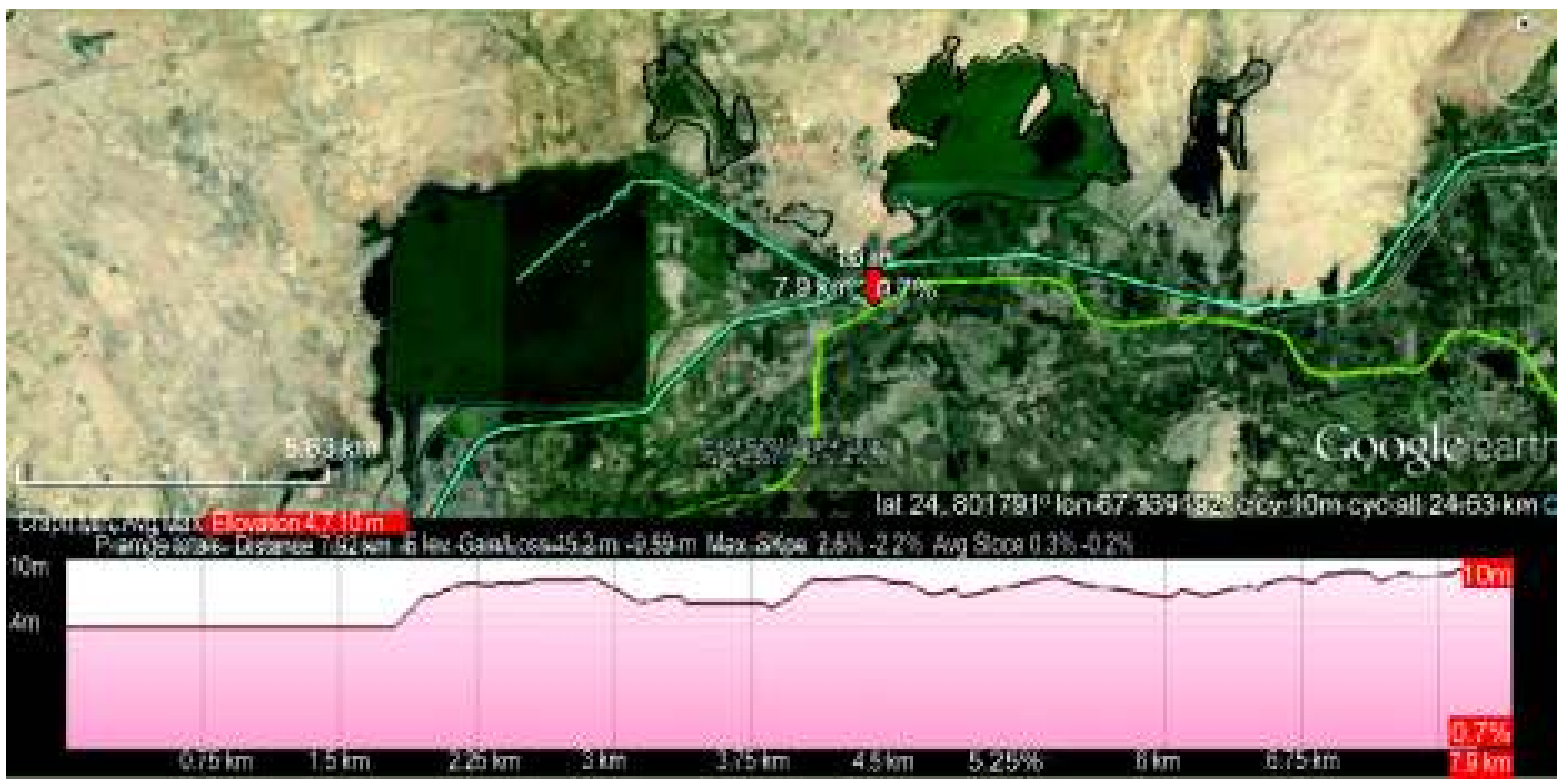

Fig. 5. Elevation profile of Jamwah Canal feeding Haleji Lake.

The inter-connectivity of all wetlands (Keenjhar wetland complex and Haleji wetland complex) is feasible as mentioned in Fig. 6. The Hadero Lake and suggested point at KB feeder as well as Keenjhar-Gujjo Canal had a drop of $5 \mathrm{~m}$ to feed the Hadero Lake as well as a wetland near Hadero lake. Hadero Lake can be washed to reduce the salt concentration as RBOD drain is passing beside the Hadero Lake which can be used to remove the excess salt water.

Similarly the Jamwah branch can be connected with Chhateji Lake and the wetland near Haleji to revive the Haleji wetland complex through natural water ways which are now either occupied by land grabbers or

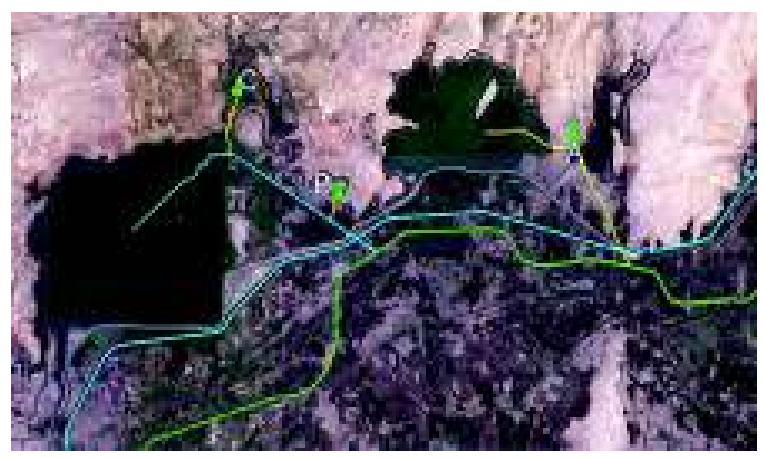

Fig. 6. Inter-connecting possibilities of adjacent wetlands washed due to weathering process. Natural depressions can be revived not only to increase the water conservation capacity but can be effective to re-vitalize the depleting environment and natural habitat of coastal wetlands.

The storage capacities of different wetlands were calculated in Table 3 using cut and fill volume process in Global mapper v 18. The wetted perimeter polygons were prepared in Google map and exported as KML files to Global mapper.

The KML files of wetlands were imposed on ASTER GDEM V2 to get the $\mathrm{Z}$ axis values of depressions. The cut and fill volume option in Global mapper divide the entire polygon of each wetland in meshes of different default sizes as per wetted perimeter area of particular polygon. The volumes are then calculated using cut and fill method in cubic meters.

Table 3. Area and volumetric capacities of wetlands

\begin{tabular}{lll}
\hline \hline Wetland & $\begin{array}{l}\text { Area } \\
\left(\mathrm{Km}^{2}\right)\end{array}$ & $\begin{array}{l}\text { Volume } \\
(\mathrm{BCM})\end{array}$ \\
\hline Keenjhar Lake & 133.61 & 21.75 \\
Hadero Lake & 9.14 & 0.142 \\
Lake near Hadero & 1.92 & 0.031 \\
Haleji Lake & 17.46 & 0.066 \\
Chhateji Lake & 0.33 & 0.003 \\
Lake near Haleji & 2.16 & 0.028 \\
Total & 164.62 & 21.96 \\
\hline \hline
\end{tabular}


Total amplified wetland areas will be increased upto $164.62 \mathrm{~km}^{2}$, while the storage capacity can be increased from $21.75 \mathrm{BCM}$ to $21.96 \mathrm{BCM}$. This will provide additional supply of water to cosmopolitan Karachi.

\section{Conclusion}

The detailed field survey and remotely sensed analysis of the study area confirms the possibility of connecting Keenjhar Lake as well as KB Feeder with Hadero, Haleji and adjoining dried wetlands, not only for their revival but to increase the water holding capacities of main wetlands (Haleji and Hadero). The water can be stored in the identified three adjoining wetlands during flooding/ monsoon periods.

The study confirms the interconnecting possibilities of KB Feeder and Keenjhar-Gujjo canal with all wetlands to increase the storage capacity of drinking water to cosmopolitan Karachi.

The connectivity of Hadero Lake with Keenjhar Lake and/or KB Feeder which will improve the water quality in the Hadero Lake and turn it into the fresh water Lake.

Keeping in view the environmental degradation, loss of aquatic habitat, and destruction of wetlands, it is suggested to allocate separate water budget for revival of wetlands for future harvesting of water and ground water recharge.

Illegal water courses and water lifting for irrigation purpose should be strictly discouraged by local administration to give due share of water to wetlands.

Further studies should be conducted on socio-economic impacts of wetlands and KAP survey of villages around wetlands/ water bodies for increasing awareness and behavioral change.

\section{Acknowledgement}

The authors are grateful to the communities around Keenjhar, Haleji and Hadero Lakes for their warm welcome and consuming time with team. Thanks to the curator of Haleji Lake and his staff during walk-thru survey. Thanks are also due to support of PCRWR, Islamabad, for water sample analysis at DRIP, TandoJam, Pakistan.

\section{References}

Aziz,F., Azmat,R., Jabeen, F., Bilal, B. 2013. A comparative study of physico-chemical parameters of Keenjhar Lake, Thatta, Sindh, Pakistan. International Journal of Advanced Research, 1:
$482-488$.

Fisher, B., Turner, K., Zylstra, M., Brouwer, R., Groot, R.D., Farber, S., Balmford, A. 2008. Ecosystem services and economic theory: integration for policyrelevant research. Ecological Applications, 18: 2050-2067.

Fraser, L.H., Keddy, P.A. 2005. The World's Largest Wetlands: Ecology and Conservation. 446p. Cambridge University Press, Cambridge. ISBN: 9780511113864.

Golden, H.E., Lane, C.R., Amatya, D.M., Bandilla, K.W., Kiperwas, H.R., Knightes, C.D. 2014. Hydrologic connectivity between geographically isolated wetlands and surface water system: A review of select modeling methods. Environmental Modeling \& Software, 53: 190-206.

Greb, S.F., DiMichele, W.A., Gastaldo, R.A. 2006. Evolution and importance of wetlands in earth history. In: Wetlands Through Time, G. F Greb and W. A. Michele (eds.), Geological Society of America Special Papers. 399, pp. 1-40.

Kazmi, J., Qureshi, S., Siddiqui, M.U. 2006. Depleting Wetlands of Lower Sindh, Pakistan: A SpatioTemporal Study through Satellite Remote Sensing. 1 - 5. 10.1109/ICAST.2006.313786.

Khan, M. Z., Jabeen, T., Ghalib, S. A., Siddiqui, S., Alvi, M. S., Khan, I. S., Yasmeen, G., Zehra, A., Tabbassum, F., Hussain, B., Sharmeen, R. 2014. Effect of right bank outfall drain (RBOD) on biodiversity of the wetlands of Haleji wetland complex, Sindh. Canadian Journal of Pure and Applied Sciences, 8: 2871-2900.

Khan, M. Z., Abbas, D., Ghalib, S. A., Yasmeen, R., Siddiqui, S., Mehmood, N., Zehra, A., Begum, A., Jabeen, T., Yasmeen, G., Latif, T. A. 2012. Effects of environmental pollution on aquatic vertebrates and inventories of Haleji and Keenjhar lakes: Ramsar sites. Canadian Journal of Pure and Applied Sciences, 6: 1759-1783.

Koning, F. J., Walmsley, J. G. 1972, IWRB mission to West Pakistan. IWRB Bulletin,. 33, pp. 42-51.

Mahessar, A. A., Qureshi, A. L., Mukwana, K. C., Jakhrani, A. Q. 2015. Study of environmental impacts and threats to the Ramsar Haleji Lake, Sindh, Pakistan. International Journal of Applied Environmental Sciences, 10:1577-1590.

Marsooli, R., Orton, P.M., Georgas ,N., Blumberg ,A.F. 2016. Three-dimensional hydrodynamic modeling of coastal flood mitigation by wetlands. Journal 
of Coastal Engineering, 111: 83-94.

Qureshi, A. L., Mahessar, A. A., Leghari, M. E. H., Lashari, B. K., Marri, F. M. 2015. Impact of releasing wastewater of sugar industries into drainage system of LBOD, Sindh, Pakistan. International Journal of Environmental Science and Development, 6: 381-386.

Savage, C.D.W., Isakov J.A. 1970. International cooperation in management of waterfowl and wetlands in Asia, Project Marine Pakistan. Journal of Forestry, 20: 387-391.

Savage, C.D.W. 1967. The Wildfowl and wetland situation in West Pakistan. Proceedings Technical Meeting on Wetland Conservation, Ankara-BursaIstanbul, 9-16 Oct,1967. IUCN Publication New Series No.12: 122-128.
Seminara, G., Lanzoni, S., Cecconi, G. 2011. Coastal wetlands at risk: learning from Venice and New Orleans. Journal of Ecohydrology and Hydrobiology, 11: 183-202.

Walters, K.M., Sebens, M.B. 2016. Using climate change scenarios to evaluate future effectiveness of potential wetlands in mitigating high flows in a Midwestern U.S. Journal of Ecological Engineering, 89: 80102.

WWF, 2017. Threats to wetlands. http://wwf.panda.org/ about_our_earth/about_freshwater/intro/threats/ 21: 11.2017 .

Zhao, Q., Bai, J., Gu, B., Lu, Q., Gao, Z. 2016. A review of methodologies and success indicators for coastal wetland restoration. Ecological Indicators, 60: 442-452. 